\author{
Ilga Jansone, Anna Stafecka \\ Latvian Language Institute \\ of the University of Latvia \\ Riga
}

\title{
ATLAS OF THE BALTIC LANGUAGES: PLANT NAMES OF SLAVONIC ORIGIN
}

Latvian and Lithuanian are the only Baltic languages still alive. They both have historically developed regional territorial dialects. Traditionally, three Latvian dialects are distinguished. Middle dialect is spoken in Kurzeme, Vidzeme and Zemgale. For the Livonian dialect, the area of distribution is Northern Kurzeme and North Western Vidzeme. High Latvian dialect is used in the eastern part of Latvia. The Latvian dialects are further divided into 500 small territorial units called subdialects which are united in certain groups.

Lithuanian language has two main dialects: Aukshtaitian and Zhemaitian. Lithuanian dialects are also divided into groups of subdialects, these groups containing more than 700 smaller dialectal units.

Historical regional dialects are relatively well-preserved both in Latvia and Lithuania. Nevertheless, nowadays they are disappearing. This was the reason why the dialectologists of the Latvian Language Institute of the University of Latvia, and the Department of Language History and Dialectology of the Institute of the Lithuanian Language, have developed a joint project entitled Atlas of the Baltic Languages, which is intended to demonstrate the close kinship of these two Baltic languages. In 2009, the pilot project volume of the Atlas of the Baltic Languages, including 12 geolinguistic maps with commentaries in Latvian, Lithuanian and English, was published (ABL 2009).

It has to be mentioned that for more than a century, research on Latvian and Lithuanian dialects was carried out parallelly, but separately, gathering data on the various dialects of each respective language (the recording of dialectal vocabulary of both Baltic languages began in the $2^{\text {nd }}$ half of the $19^{\text {th }}$ century, when special programs for gathering folklore and ethnographic and linguistic data were elaborated), see [Mikulèniene, Stafecka $2011 ; 2012]$. Only in the $2^{\text {nd }}$ half of the $20^{\text {th }}$ century, Latvian and Lithuanian vocabulary was recorded using a united questionnaire for the Atlas linguarum Europae (ALE).

Dialectal material collected for the national atlases of Latvian (LVDA) and Lithuanian (LKA), representing 500 subdialects in Latvia and more than 700 in Lithuania, 
as far as information on Latvian and Lithuanian dialects for the Atlas linguarum Europae dealing with 36 Latvian and 42 Lithuanian subdialects, constitute the basis of the Atlas of the Baltic Languages.

It was also necessary to look for common methods of presenting the dialectal material on the geolinguistic maps, because of different national geolinguistic traditions and different ways of presenting dialectal material on the maps of national atlases. It has been decided not to indicate the traditional borders of the Latvian subdialects, because they have retained the no-longer existing 1939 borders of local civil parishes. Thus the areas on the maps where the Latvian and Lithuanian languages are spoken were joined into one common map for the Atlas of the Baltic Languages (see Fig. 3; more in details see [Leskauskaite, Mikulenienè 2010: 59-64]).

Five volumes are planned for the Atlas of the Baltic Languages, presenting the dialectal vocabulary in thematic groups:

- flora-related vocabulary (names of plants and trees);

- fauna-related vocabulary (names of insects, reptiles, birds, wild and domestic animals, etc.);

- physical and mental human qualities and kinship terminology (e.g., to ask, to like, to remember, lazy; family members, relationship terms, etc.);

- housing and settlement (e.g., words for village, garden, fence, terms related to agriculture, home trade, meals);

- natural phenomena, time, weather, etc. (e.g., names of clouds, rainbow, midnight, etc.).

In 2012, the first volume of the Atlas of the Baltic Languages, Lexis 1: Flora has been published in CD format (ABL 2012). This volume presents the part of the vocabulary characteristic of the Baltic languages on a wider scale. It introduces a comprehensive introductory article, 16 linguistic lexical maps and commentaries in Latvian, Lithuanian and English, as well as 15 smaller maps where the name of one or another plant is shown in the area of prevalence only in one of the languages in Latvia or Lithuania. The readers can also get acquainted with the history of the geolinguistic research conducted by the scholars of the two countries in the 2 nd half of the $19^{\text {th }}$ and $20^{\text {th }}$ centuries.

Flora-related vocabulary includes names of:

- wild plants, e.g., cornflower, nettle, waybread, milfoil, dandelion, plantain;

- cultivated plants, e.g., onion, potatoe, garlic, cucumber, Swedish turnip, [winter] wheat;

- trees (juniper, hazel-tree, pear-tree, plum-tree, cherry-tree, etc.) and words related to a tree (top of the tree, cone, etc.).

Plant names mostly are words of Baltic or IE origin, e.g., Latv. nätre / Lith. notryne 'nettle', Latv. cela lapa / Lith. kelio lapas, Latv. dzīslene / Lith. gyslotis 'plantain', Latv. kvieši / Lith. kviečiai 'wheat', Latv. grieznis / Lith. griežtis 'Swedish turnip'. Nevertheless, borrowed plant names also occur in both Baltic languages. In most cases they are loanwords from German or Slavonic (Polish, Russian, Belorussian) languages. In this article, some borrowed plant names from Slavonic languages reflected in the Atlas of the Baltic Languages, Lexis 1: Flora are analysed. 
The following main groups of borrowed plant names can be distinguished:

\section{Common borrowings located in a wide area in Lithuania and used all over Eastern part of Latvia - the region of Latgale}

Some loanwords from the Slavonic languages are widespread in the dialects of both languages in a large common area. Mostly they are names of cultivated plants and trees which, because of historical conditions, are borrowings from German elsewhere in Latvia (the regions of Kurzeme, Vidzeme and Zemgale), but in Lithuania and the eastern part of Latvia (Latgale) their equivalents are Slavonic borrowings.

Common Slavonic widely distributed borrowings usually are the names of some vegetables and fruits. Among the most well-known are the names of the potatoe (Solanum tuberosum) - Latv. bulve and its variants, buḷba and variants, ulıbiks / Lith. bulve and variants, bulbe and variants (see Fig. 1).

Lith. bùlvè, which has become established in the standard Lithuanian language, is frequent in Lithuanian dialects.

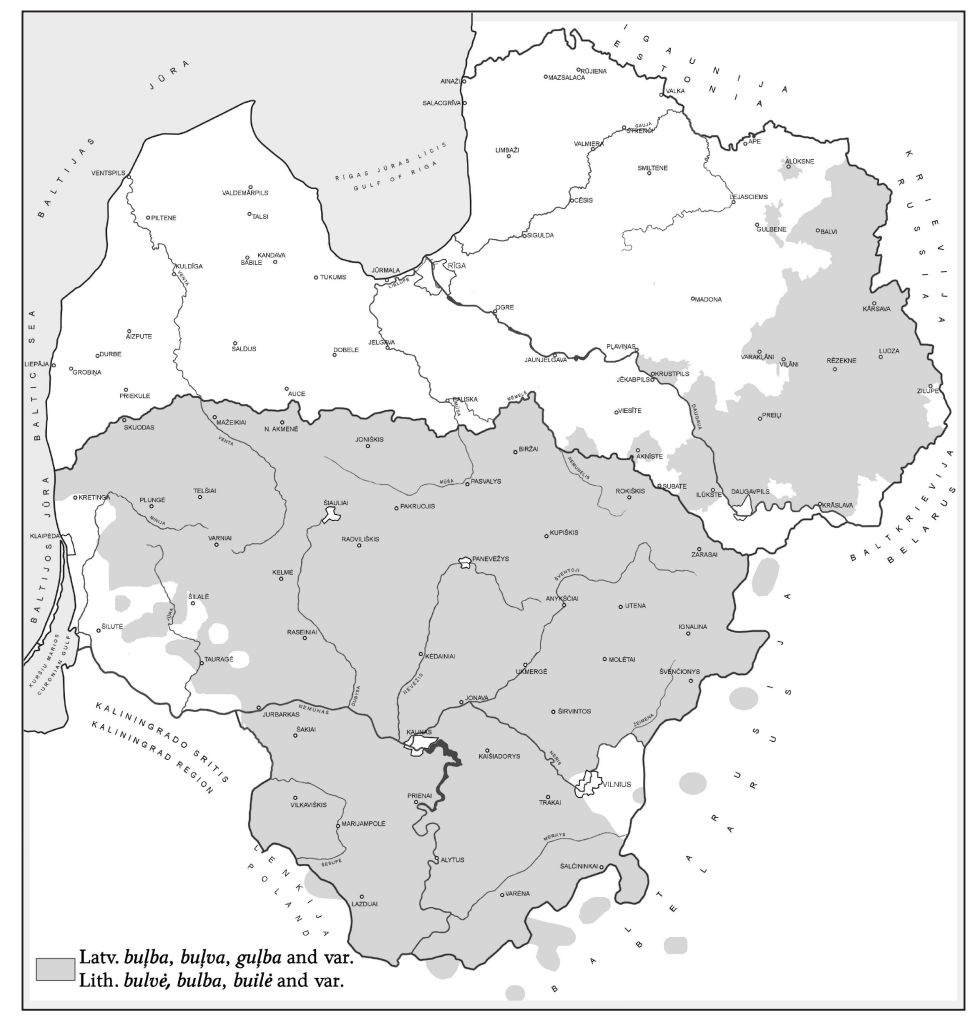

Fig. 1. Distribution of Latv. buḷve and variants, Lith. bulvé and variants - 'potatoe (Solanum tuberosum)' 
It is the most characteristic name in Kaunas district, but is also found in the subdialects around Alytus, Lazdijai and Kedainiai. This name is also used in the northern subdialects of the eastern Aukshtaitian of Panevėžys, in the subdialect of the northern Zhemaitian in Kretinga district and in the north-western corner of Telšiai around Skuodas. The variant bùlva is used around Utena, Zarasai, Rokiškis. On the basis of the material in Antanas Juška's dictionary of the $19^{\text {th }}$ century, we can conclude that earlier it might have been used in some western Lithuanian subdialects, too.

The names with the root bulv v- (bùlıa, bùlıve, bùlvis and bùlvs) are widespread in a large area in the Eastern part of Latvia - the subdialects of High Latvian dialect in Latgale, more rarely in Augšzeme.

The names bulbe, bulba are common in a large part of the area of the Lithuanian language. The first of them - bùlbe and variants - is used by many Zhemaitians: furthermore, it is also used in almost the entire area of the western Aukshtaitians of Šiauliai, and in the south-eastern subdialects of the eastern Aukshtaitians of Panevėžys area.

The name bùlba is common in the entire area of the subdialects of southern Aukshtaitians, eastern Aukshtaitians of Vilnius, Utena, Anykščiai, Kupiškis, Širvintos areas, in eastern and central areas of the subdialect of Panevezzys, as well as in the south-western area of the Šiauliai Aukshtaitians around Jonava, Kèdainiai. This word is used in Dieveniške s and in many Lithuanian subdialects in Belarus: around Breslauja, Apsas, Kamojys, Lazūnai, Gervečiai. In the area of the northern Zhemaitians around Plunge and Kretinga, the name buile is found.

Very similar words with the root bulb- are registered in the eastern area of Latvia, especially in Latgale and in some places in Augšzeme. Most common are the follow-

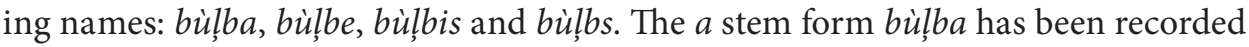
in Selonian subdialects of Zemgale (around Aknīste, Laši) and in most subdialects of Latgale. The e e stem form bùlbe is used in this area, too. The iino stem form bul bis is recorded in the northern subdialects of Latgale (around Liepna, Viliaka).

The words ulbiks and ulbikis most likely represent apheresis of the initial $b$ - of the stem buḷb-. The name ìllbiks has been registered in Nautrēni and some neighbouring subdialects. [ME IV 297] presents the variant ulbiķis from Domopole (Bērzpils) and Zaļmuiža (Nautrēni), and [EH II 712] - from Bērzgale. It is not recorded in other collections.

The names bulve and bulbe (with their variants) are borrowed from Pol. bulwa, bulba, Bel. бу́льба, бу́льва (cf. [ЭСБМ I 410; LEW 63; Smoczyński 2007: 80]). They are Germanisms, cf. Germ. Bolle 'bulb, onion' [Фасмер I 240; Sabaliauskas 1990: 238].

Lith. bùlbe, as well as bùlve, was known since the middle of $19^{\text {th }}$ century, it was used by Simonas Daukantas. The Latvian written sources of the $19^{\text {th }}$ century contain the nom. pl. form bulbes, $-u$, Kartoffeln (from Bebrene), see [Ulmann 1872: 39; bulbes Ulmann 1880: 439].

In the both Baltic languages, there are also some names for garlic that are common Slavonic borrowings: Latv. casnags, casnägs and variants, and Lith. česnākas and its variants (see Fig. 2). They constitute a large common area of distribution in the whole territory of Lithuania and in the eastern and north-eastern part of Latvia - i.e. Augšzeme, Latgale and North-Eastern Vidzeme. 
According to the data of ALE, the most widespread Lithuanian word for garlic is česnakas, which belongs to standard language vocabulary and is used in the whole country. Česnakas has also been recorded in Lithuanian subdialects spoken in Belarus. This word has several phonetic variants, most of them used in the Zhemaitian dialect: česnãgas, čišnãgas, in southern Zhemaitian subdialects also: cesnãkas, cesnãgas, cisnãgas, cicnãgas. The variant čisnãkas is also used in Zhemaitian subdialects, it has been registered in Šilute, Judrenai and Vismaldai, more seldom in the western Aukshtaitian subdialects around Kaunas. In northern Zhemaitian subdialects one can encounter words with other phonetic transformations - šešnãkas, šešnãgas, šašnãgas, šišnakas, šišnagas. The variants česnikas, česnõkas are registered in Lithuanian subdialects in Belarus - Zietela and Lazūnai.

In Latvia, the word casnags is registered in northern, eastern and some central subdialects of Latgale; casnāgs is characteristic of some Augšzeme subdialects and southern subdialects of Latgale, along with the variants casnaks and casnāks. The variants cosnags and cosnaks are mostly observed in northern subdialects of Latgale. In Augšzeme, as well as in some southern subdialects of Latgale (e.g. in Vārkava, Kalupe, Višķi, etc.), the variants časnags, časnāgs, časnaks, časnāgs, etc. have been registered, see [LVDA map no. 48 and commentary].

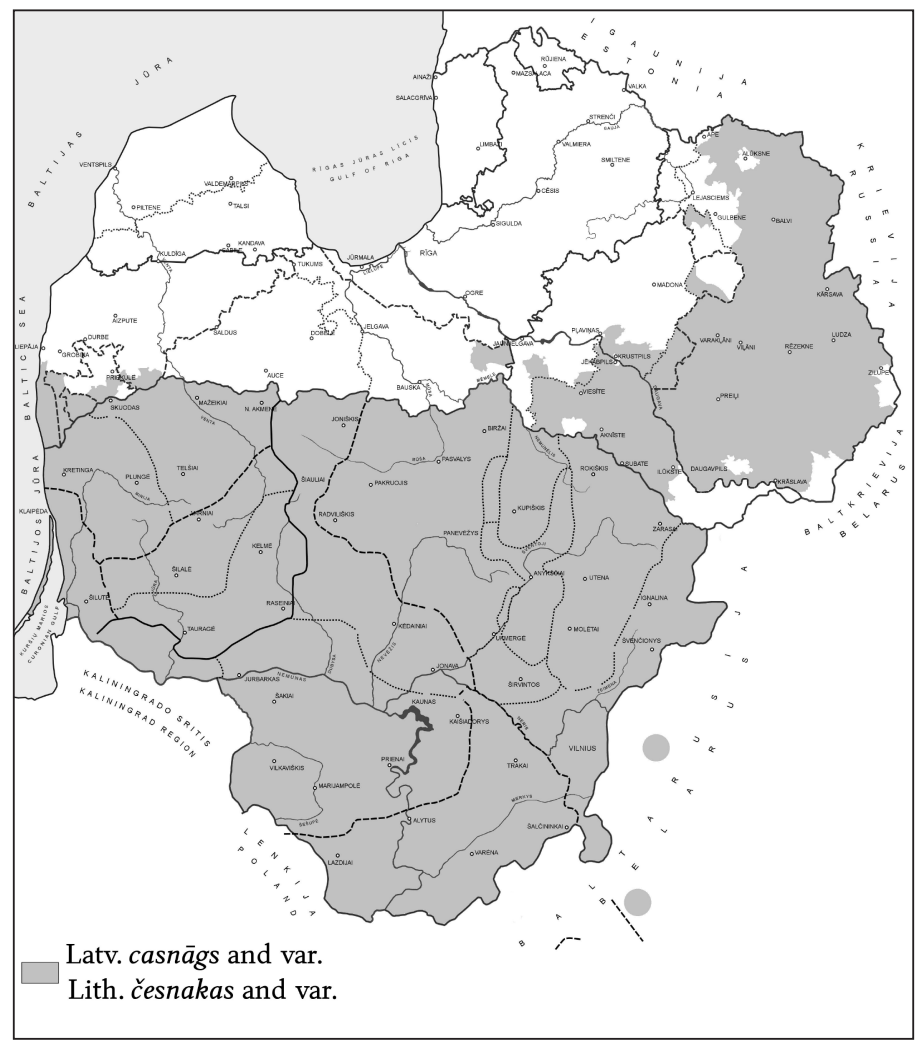

Fig. 2. Distribution of Latv. casnāgs and variants, Lith. česnakas and variants 'garlic (Allium sativum)' 
These Slavonic names of garlic are borrowed from Russ. чеснок, Bel. чеснок, часно́к, часна́к, чócнак, Pol. czosnek (see [LEW 73; Sławski II 175; Sabaliauskas 1990: 238]).

Časnoks and časnaks are mentioned in written sources of $18^{\text {th }}$ and $19^{\text {th }}$ century: časnoks - in the dictionary of Jan Kariger's [Kolbuszewski 1977: 186-187]; časnaks - in Jan Kurmin's dictionary: Czosnek. Allium. Czosnaks, v. czasnaks [Kurmin 1858: 21].

It has to be mentioned that šišn,naks, sišnnaks, šišnaks are registered in South-Western Kurzeme as well. Probably in this area it has been borrowed from Slavonic languages through northern Zhemaitian subdialects of Lithuanian.

Dialectal name of cucumber (Cucumis sativus) - Latv. agurks and variants / Lith. agurkas and var. - is also common in Lithuania and in the eastern part of Latvia. It is an old loanword from the Slavonic languages, cf. OBel. огурокь, OPol. ogurek, see [Būga III 322].

Names of some berry bushes and fruit-trees are also used all over Lithuania and Latgale - e.g., Latv. agrasta, agresta and variants / Lith. agrastas and variants, cf. Pol. agrest, Bel. árpэcm 'gooseberries (Grossularia reclinata)'; Latv. vǐšna / Lith. vyšnia, cf. Russ. вишня, Bel. вішня, Pol. wiśnia, 'cherry (Cerasus)'; Latv. šliva, šlivka / Lith. slyva and variants, cf. Russ. сливa, Pol. śliwa, śliwka 'plum (Prunus)'; Latv. gruša, gruža, gruška / Lith. grūšia 'pear (Pyrus)'.

The name grüšia 'pear' in the meaning of a tree was once recorded as early as the $16^{\text {th }}$ century, in Mikalojus Daukša Postille: wêliième iimé turét' óbelis / grûßias / ir kítus mêdžius 'we want to have apple-trees, pear-trees and other trees in it' [DP 558, 40]. The same meaning is also found in the second dictionary of Konstantinas Sirvydas in the $17^{\text {th }}$ century where grüšia is given alongside another Slavonism dülia.

In some manuscript dictionaries of Lithuania Minor in the $17^{\text {th }}$ century, the variant grūše of the word grū̌šia that appeared due to merging of $i \bar{a}$ and $\bar{e}$ stems (cf. [Ambrazas 1993: 32]) denotes a fruit of a pear tree. The word grüšià and its variants are used in both meanings in later writings and dialects.

These names were and still are used in almost all subdialects of Aukshtaitian and Zhemaitian dialects (see [ABL 2012, 508-509]).

The Lith. words grüšnià, grùšnia and other variants most likely have originated from Bel. грушня 'pear' (most probably derived from the adjective *grušbnzjø 'pearshaped', cf. [ЭССЯ VII 157]). These names are known from some subdialects in the Klaipeda area, spoken by western and eastern Zhemaitians.

According to the map No. 2 of Dialectal Atlas of Latvian (LVDA 1999), the name gruša (cf. Russ. грyua) is used all over Latgale, with the exception of some south-western, north-western and southern subdialects, and the word gruška (cf. Pol. gruszka) - around Rēzekne, Viḷāni, Kalupe, Aglona, Krāslava. The word gruža has been recorded near Rēzekne - in Makašēni and Nautrēni.

Other variants most probably borrowed from the Slavonic languages have been recorded in Lower Kurzeme: grūša, grūšis and grūšsu kuoks in Rucava, and grūšse in Dunika. Probably in this area they were borrowed from Slavonic languages through Lithuanian. 
The variant gruškakuoks (Gruska-koks) is mentioned in Georg Elger's dictionary [Elger 1683: 99], and grušņa kuoks - in Jan Kurmin's dictionary - Gruszka drzewo. Pyrus. grusznia kuks [Kurmin 1858: 37].

\section{Common borrowings located in wide area in Lithuania and used in some subdialects in Latgale}

Some names of plants of Slavonic origin are mostly widespread in Lithuania but occur rarely in the subdialects of Latgale.

The Slavonisms of the same origin vosilka / vasilka (cf. Bel. васілекъ, Pol. wasitka, wasilek 'cornflower' [ЭСБМ V 72], Russ. василе́къ [Даль I 167], see [Skardžius IV 298]) are used in the meaning of cornflower (Centaurea cyanus) in Lithuanian and Latvian dialects. They form a common area of distribution (see Fig. 3).

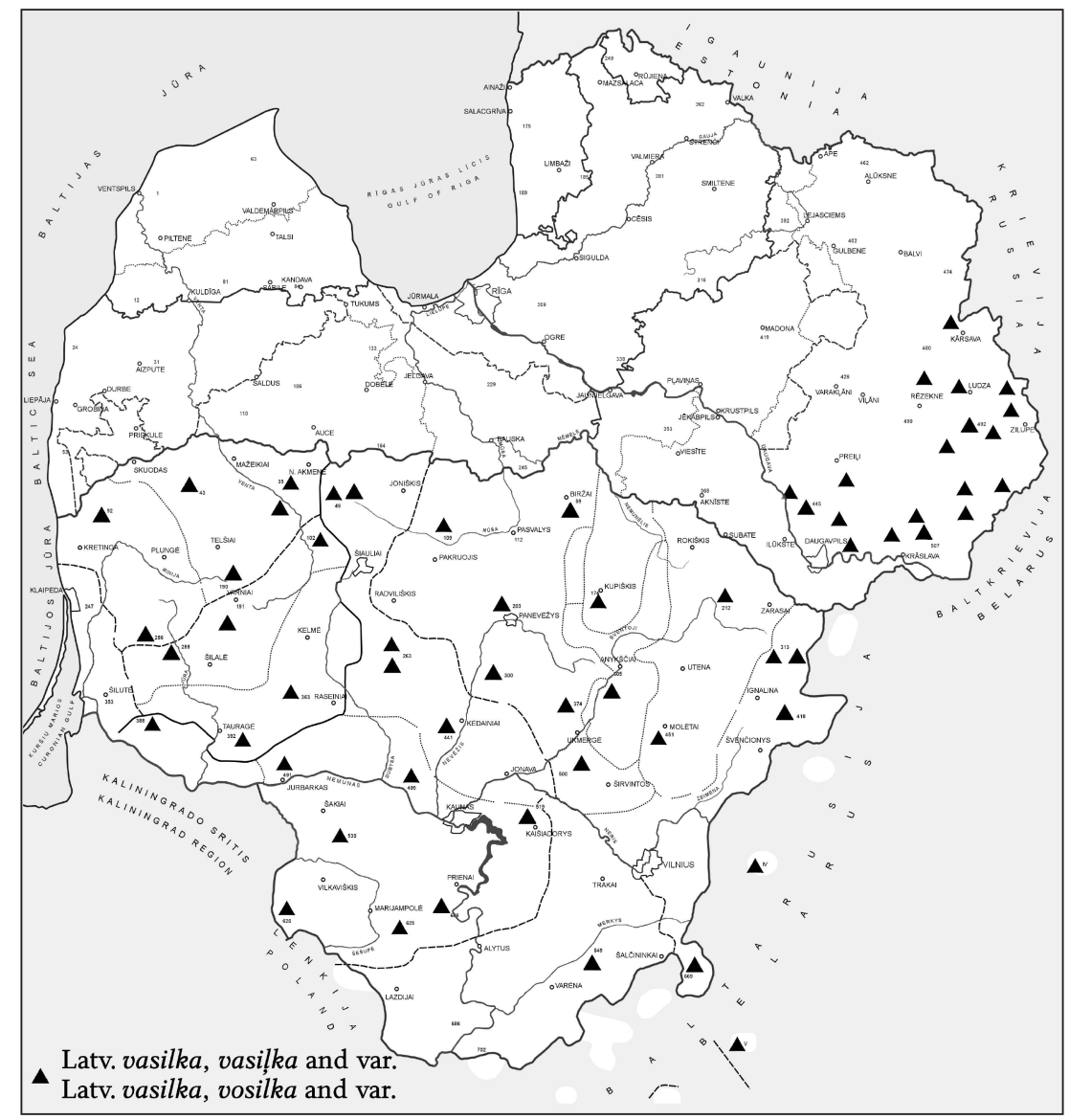

Fig. 3. Distribution of Latvian and Lithuanian vasilka (Centaurea cyanus) 'cornflower' and its variants 
Lith. vosilkà (and its variants) is characteristic of all Lithuanian dialects. The name vosilkà was recorded as early as in the $17^{\text {th }}$ century: in both dictionaries of Konstantinas Sirvydas: modrak / caliba, calen-\|dula, wo fitka [SPr 83]; Modrak / modrzeniec. Cyanus. Wofitka [SD3178]; in the first manuscript of German-Lithuanian dictionaries of Lithuania Minor; e.g.: Kornbluhm Wofilka [Lex 55a]; Korn=Bluhme. Wofilka, ôs, [F. C I 1099].

The variant vasilka with the vowel $a$ in the root is also used in dialects. The gradation of the vowels $o$ and $a$ is quite a frequent phenomenon in Lithuanian Slavonisms (cf. [Zinkevičius 1997]).

Latv. vasilka is used in the east and south of Latgale. In some subdialects, other variants of this name have also been recorded - vuosilka (Kalupe), vosilka (Izvalta).

Some names for the yarrow (Achillea millefolium L.), which have originated from the noun kraũjas 'blood', are related to Pol. krwawnik 'yarrow', Bel. крываўнік, крыво́ўнік, Russ. dial. кровавник (see [ABL 2012: 425-426; ЭСБM V 128]).

The Slavonism kriváunykas with its variants is widespread in a large area of Lithuania. In some places there still are words formed with different alterations, e.g., with the root vowel $e$ (showing the influence of Pol. krew 'blood'): kreváunykas, kreváuninkas, krevãvnykas, krevuovninkas, etc.; with the root vowel a: kraváunykas, kravaunỹkas; kraváuninkas (they were influenced by Russ. кровь, Bel. крой 'blood'); with the root vowel u: kruváunykas, kr(i)uváuninkas, kurváunykas, kurváuninkas (here a relation with Lith. krùvinas is possible); with the compound suffix (also of Slavonic origin) -alnykas / -alninkas: kraválnykas, kriválninkas, kraválninkas, kruválninkas; shortened forms: kráunykas, kr(i)áuninkas; kraválkas. A rare Slavonisms kriváuka of a different formation with its variants krivaukà, krivúnka was also found (more in details see [ABL 2012: 426]).

Such Slavonisms are used in some subdialects of Latgale, e.g.: kravniks in Rundēni, kravavniks in Pilda, Rundēni, krival̦ieki, krivavniks in Ezernieki, krivovka in Šķaune, krovavniki in Mërdzene, Pilda, Skaista (see [LVDA, map no. 16 and commentary]).

The name of the cone šiška (and its variant šišks) is registered in some subdialects of Eastern Latgale (around Cibla, Istra, Kaunata, Nirza, Pilda, Zvirgzdene and other places), as well as Southern Latgale (around Kapin̦i, Naujene, Skaista, Višķi). It was derived from Bel. шъішка, Russ. шишка or Pol. szyszka 'cone' (cf. [Skardžius IV 115]).

The area of the use of Lith. šyška with its variants is much wider, it covers a part of the territory where the Aukshtaitian dialect is spoken (especially eastern subdialects). There are two more distant phonetic variants in Lithuanian dialects: šyčka, šyčka and its variants is used in some subdialects of eastern Aukshtaitians of Vilnius, western Aukshtaitians of Kaunas area, and southern Aukshtaitians; čyčkà, č́y ýka; čyškà; čy ččkas is characteristic of western Aukshtaitians in Kaunas district. The latter čyčka was recorded alongside the Lithuanian name of the cone as early as in the $17^{\text {th }}$ century in manuscript dictionaries of Lithuania Minor. The word čečka and its variants is also mentioned in the dictionaries of that region published later (see [LEW 72; e-LKŽ]).

In Lithuanian-speaking areas in Belarus, along with the Lithuanian word aviete 'raspberry (Rubus idaeus)' the Slavonic borrowing malina / malyna is also used. 
Some separate south-eastern and central subdialects of Latgale (in Asūne, Ezernieki, Kapiṇi, Kaunata, Naujiena, Rèzna, Rundēni, Skaista, Šķaune) also use the word maļina, usually along with some of the words with the root $a v$-. The word malina is Slavonic borrowing (cf. Russ. мали́на, Ukr. мали́на, Bulg. мали́на, Serb. and Croat. ма̀лина, Slov. malina, Cz. malina, Pol. malina), etymologically related to Lith. mélynas 'blue', Latv. meslns 'black'. A less credible interpretation associates it with Gr. $\mu \eta \lambda o v$ 'sheep', Ukr. маль 'young sheep' (see [Фасмер II 563]).

The names for the vegetable with edible leaves and round underground bulb called the onion (Allium Cepa) in the Lithuanian and Latvian languages also are loanwords (cf. [Sabaliauskas 1958; Urbutis 1981: 192f]). The most widespread and common to both languages is Lith. cibùlis / Latv. dialectal cibulis. The material of the Atlas linguarum Europae shows that Lith. cibùlis is used in all Lithuanian dialects. Alongside these names, other variants of the loanword cibùlis are also used: cibùle and čibùlis (concerning the consonant $c$ instead of $c$, see [Urbutis 1981: 193]).

The loanword cibulis is rare in the Latvian language. However, it is used in a compact area in the southern Latgalian subdialects. The name of the onion cibulis has been recorded in one of the Selonian subdialects of Zemgale, in Rite. [ME I 412] has also recorded the name of the onion čibuli (with the note „jargon”), and indicated that it is used around Bērzaune. Lith. cibùlis / Latv. cibulis are loanwords from OPol. cybula. The latter is a hybrid Germanism from WHG Zibolle, Zebulle [Brückner ${ }^{2}$ 1957: 56].

The following names could be treated in a similar way: cibulis (in Agurkiškè, Kazlų Rūda), cìbule (in Rusnè, Plaškiai, Žemaičių Kalvarija, Lyduokiai); cỹpuolè (in Kunigiškiai), ceip̃pulis (in Užubaliai); sibulis (in Pakruojis), sibùlis (in Bitènai, Sukaičiai, Viešvilè, Smalininkai, Sudargas, Jurbarkas, etc.); zibùlis (in Barzdai). Interchange of consonants $s, c$, $z$ has also been noticed in other Germanisms of the Lithuanian language (cf. [Čepienè 2006: 292]). Lith. cypule known in Plikiai is also treated as Germanism, cf. East Prussian German Zippel and E. Kuršaitis’ cibūlè, cf. LG Zibbel [Urbutis 1981: 192]. The variant cibulia was recorded in the manuscript Deliciae Prussiciae (by Motiejus Pretorijus in 1690). The variant cebùle, cẽ bulè was recorded in the writings of Jurgis Ambraziejus Pabrèža in the $19^{\text {th }}$ century, and now it is used in some subdialects of Zhemaitian dialect (in Švèkšna, Viekšniai, Veiviržènai, Gargždai) and also by western Aukshtaitians (in Lenčiai) and is derived from the current Pol. cebula [Urbutis 1981: 192].

\section{Different Slavonism in Latvian and Lithuanian}

Several Slavisms registered in Latvian and Lithuanian are of different origin. For instance, names of clover (Trifolium) recorded in some eastern subdialects of Latvian and Lithuanian are borrowed from Russian and Byelorussian: Latv. klevers $(<$ Bel. dial. кле́вер, клевір, Russ. клевер which is treated as Germanism, cf. LG klewer, Engl. clover, more in details see [Fasmer II 245]), Lith. kaniušina < Bel. kанюшына, Pol. koniczyna 'clover' (see [ЭСБМ IV 243; ОЛА (4) 2012: 194]). 
The name of the plantain padarožniks has been found in some subdialects of Latgale. This was borrowed from Russ. подорожник 'plantain' where it is semantically motivated and made from two components: Russ. no 'along' + Russ. дорога 'road'. Russ. дорога 'road', like Ukr. dopoza 'road', Pol. droga 'road', is related to IE *dorgh- [Фасмер I 530]. Slav. no 'under' and Balt. pa are related to IE ${ }^{\star}$ pas- [Фасмер III 293].

The names of the plantain bóba, bobkêle are used in several Lithuanian subdialects, located outside the Lithuanian border, mainly in Lazūnai and Zietela, as well as in some places in central Lithuania (in Labūnava, Ėriškiai). Appearance of these names can be related to the use of the Slavonisms (cf. Pol. babka 'plantago' [Brückner 1957: 9]; Bel. бáбка 'Plantago L.' [ЭСБМ I: 253], Russ. ба́бка 'ditto' [Даль I: 33]). Moreover, Slavonism bóba and its derivatives sometimes denote other plants in Lithuanian dialects, taking into account their appearance (cf. [Gritėnienè 2006: 73, 77, 153]).

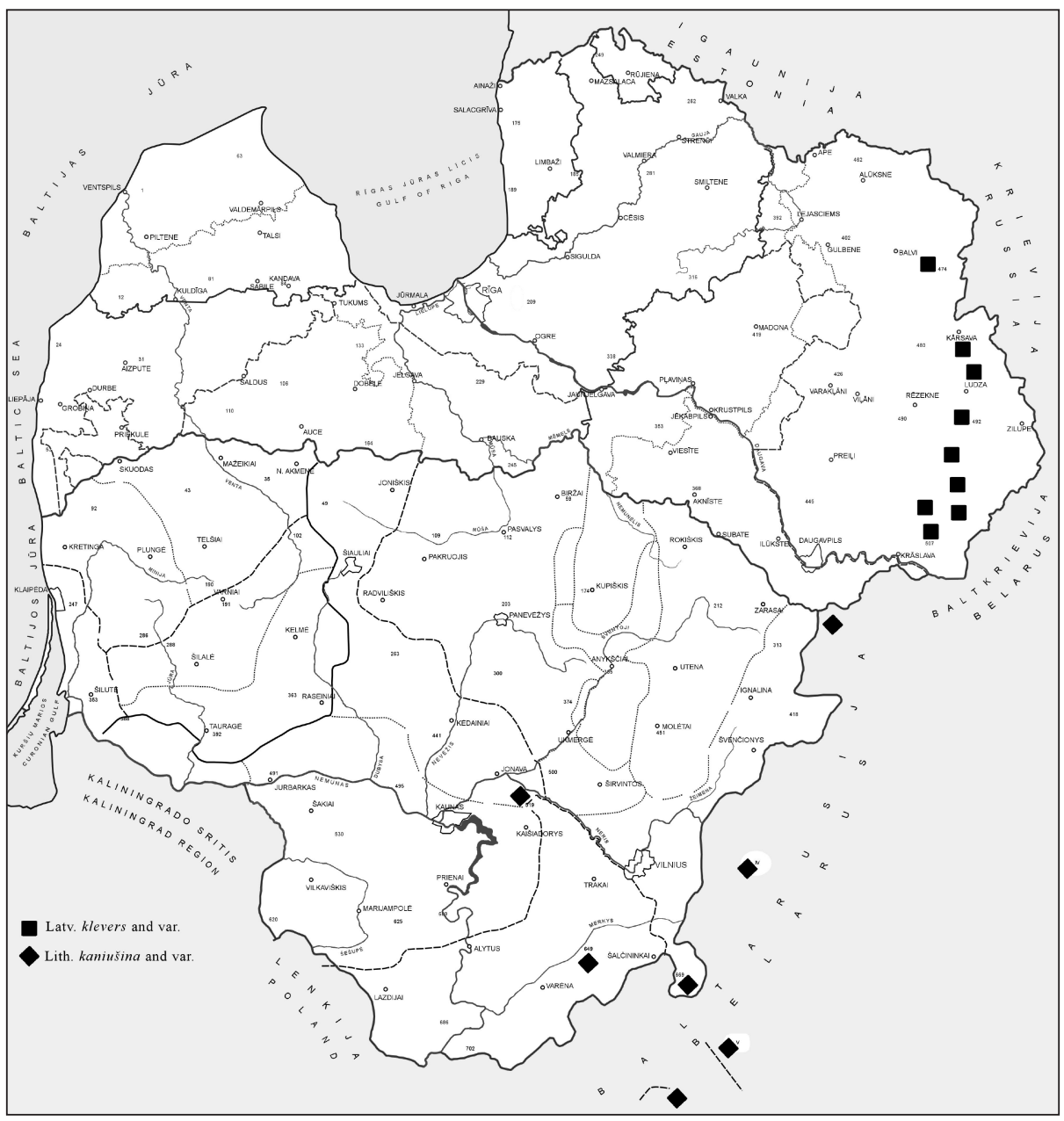

Fig. 4. Distribution of Latvian klevers and Lithuanian kaniušina 'clover (Trifolium)' 
Two names of the plantain have German or Slavonic origin. It seems likely that the name of a separate species saldati, zaldāti 'hoary plantain' (Plantago media) has been recorded in Latvian subdialects. The variant saldati has been recorded in Mērdzene, Nirza, Pilda, Rundēni, Zvirgzdene [Ēdelmane, Ozola 2003: 63], Nautrēni, Makašēni; zaldāti - in Rēzekne, zaldāteñš - in Skaista [Ēdelmane, Ozola 2003: 63]. The basis of the name is the noun saldāts 'soldier' (and the variant zaldāts). Latv. saldāts, zaldāts is a loanword from Germ. Soldat 'soldier' or Russ. солдаm 'soldier'; the latter is a loanword from Germ. Soldat, Dutch soldaat or Fr. Soldat, whose etymon is It. soldato [Фасмер III: 709]. The basis of the name is a game popular in Latgale - a scuffle with the leaves of the raceme of the hoary plantain.

The name baicele has been recorded in Ozolaine and Naujene [Ëdelmane, Ozola 2003: 58]. Another variant boicovys [Ëdelmane, Ozola 2003: 58] has been recorded in Ružina. Though all these words are presented as general names of the plantain, they all could be attributed to the names of the hoary plantain (Plantago media). Therefore these names could be related to the words saldati, zaldati and to Russ. бoŭ 'a battle' whose basis is Russ. verb бumb 'to beat'. There is also another explanation of the origin. The first component of the compound baicele can possibly be related to baice 'short thick whip' derived from Germ. Peitsche 'whip' [ME I 249].

The name of the cornflower (Centaurea cyanus) silkas, recorded around Pakruojis, semantically corresponds to Latv. zìdene, žìdene, cf. its variants šilkẽlis (around Mikniūnai, Pašvitinys), siľkas (around Gudaliai, Žemaičių Kalvarija; cf. e-LKŽ - around Kvèdarna), sillkè (around Genionys, Pūčkornès). The word šilkas is an old Slavism borrowed before the beginning of the $12^{\text {th }}$ century, cf. ORuss. щълкъ [Būga I 340]. This word or its derivatives, describing the peculiarities of blossoms, is also used to denote several other flowers in Lithuanian dialects (cf. [Gritėnienè 2006: 80, 86, 151 etc.]).

Among the names of tree-top, several Slavonisms have been recorded in Latgale: makuška in Krāslava (< Bel., Russ. макушка 'tree-top; mountain peak; top of the head') and makouka in Rundēni (< Bel. макаўкa; see [ЛАБНГ I 169]).

In some places, when denoting a cone, another Slavism bóba is also used, cf. bobùkas (Daugèliškis), bóbeliai (Linkmenys). It should be noted that this word of Slavonic origin is often used in folk names of plants (cf. [Gritenienè 2006: 77, 153]).

The origin of the name of the cone agurkas is associative, due to the similarity of the referents. This name is used around Joniškèlis, Pasvalys, Jutkonys, Kupiškis, Noriūnai, etc.

The name of the potato kurdùplis, used in the Lithuanian subdialect of Zietela, could have come through Bel. dial. карто́фля. Another name of the potato kunoda, kunodas used in Zietela is also Byelarusian, cf. Bel. dial. кунада [LKA I 161].

Very rare loanwords of the name of the nettles can sometimes be found in Lithuanian dialects. First and foremost, loanwords from the Slavonic languages krapýva, chrapýva (cf. Bel. крапіва, Russ. крапива) (Breslauja, Zietela) deserve to be mentioned, also pokrýva (cf. Pol. pokrzywa) (Troškūnai, Nemenčinè), žigùlka (cf. Bel. жыryчкa 'small nettle') (Breslauja). 
The Atlas of the Baltic Languages, reflecting the language contacts, could be an important source for further investigation not only in Baltistics but also in Slavistics and Indo-European comparative linguistics. From the distribution of related lexical and semantic phenomena we can also learn about parallels or differences of the world outlook of the ancient Balts, and the history of dialects and language contacts.

\section{ABBREVIATIONS}

$\begin{array}{lll}\text { Balt. - Baltic } & \text { Gr. - Greek } & \text { ORuss. - Old Russian } \\ \text { Bel. - Belarusian } & \text { IE - Indo-European } & \text { Pol. - Polish } \\ \text { Bulg. - Bulgarian } & \text { It. - Italian } & \text { Russ. - Russian } \\ \text { Croat. - Croatian } & \text { Latv. - Latvian } & \text { Serb. - Serbian } \\ \text { Cz - Czeck } & \text { LG - Low German } & \text { Slov. - Slovenian } \\ \text { Engl. - English } & \text { Lith. - Lithuanian } & \text { Ukr. - Ukrainian } \\ \text { Fr. - French } & \text { OBel. - Old Belarusian } & \text { WHG - West High German } \\ \text { Germ. - German } & \text { OPol. - Old Polish } & \end{array}$

\section{LITERATURE AND SOURCES}

ABL 2009 - Baltu valodu atlants. Prospekts / Baltu kalbu atlasas. Prospektas. / Atlas of the Baltic Languages. Prospect. Editing and introduction by: A. Sta fecka, D. Mikulènienè. Map commentaries by: I. Jansone, A. Stafecka, R. Bacevičūtè, A. Leskauskaitè. Map computer graphics by E. Tru mpa, L. Geržotaitè. Etymological references compiled by S. A mbraza s. - Riga / Vilnius: The University of Latvia, The Latvian Language Institute of the University of Latvia / The Institute of the Lithuanian Language.

ABL 2012 - Baltu valodu atlants. Leksika. Flora / Baltu kalbu atlasas. Leksika. Flora / Atlas of the Baltic Languages. Lexis. Flora. Editing and introduction by: A. Stafecka, D. Mikulènienè. Map commentaries by: I. Jansone, A. Stafecka, R. Bakšienè, A. Leskauskaitė, J. Meiliūnaitè. Map computer graphics by E. Trumpa, L. Geržotaitė; L. Markus- Narvila. Etymological references compiled by S. A mbrazas, R. Kregždys. - Riga / Vilnius: The University of Latvia, The Latvian Language Institute of the University of Latvia / The Institute of the Lithuanian Language.

ALE - the files of the Atlas linguarum Europae stored at the Latvian Language Institute of the University of Latvia and the Institute of the Lithuanian Language.

Ambrazas 1993 - Saulius A mbrazas. Daiktavardžiu darybos raida. Lietuviu kalbos veiksmažodiniai vediniai, Vilnius: Mokslo ir enciklopedijų leidykla.

Brückner 1957 - Aleksander Brückner. Słownik etymologiczny języka polskiego. Wyd. 2, Warszawa: Wiedza Powszechna.

Būga - Kazimieras Būga. Rinktiniai raštai I-III. Vilnius: Valstybinè politinès ir mokslinès literatūros leidykla, 1958-1961. 
Čepienè 2006 - Nijolè Čepi enè. Lietuvių kalbos germanizmai ir jų fonetinès ypatybès, Vilnius: Lietuvių kalbos institutas.

Ēdelmane, Ozola 2003 - Inese Ē delma ne, Ārija Ozola. Latviešu valodas augu nosaukumi, Rìga: Augsburgas institūts.

EH - Jānis Endzelīns, Edīte Hauzenberga. Papildinājumi un labojumi K. Mīlenbaha Latviešu valodas vārdnīcai. Rīga, 1934-1946, 1.-2. sēj.

Elger 1683 - Dictionarivm Polono-Latino-Lottauicum. Opus posthumum. R. P. Elger Soc. Jesu, Vilnae: Typis Academicis Soc. Iesu.

e-LKŽ - Lietuvių kalbos žodynas, http://www.lkz.lt/

LEW I-II - Ernst Fraenkel. Litauisches etymologisches Wörterbuch 1-2, Heidelberg: Carl Winter-Gottingen: Vandenhoeck \& Ruprecht, 1955-1965.

Gritėnienè 2006 - Aurelija Gritènienè. Augalu pavadinimų motyvacija šiaurés panevėžiškių patarmeje, Vilnius: Lietuvių kalbos institutas.

Kolbuszewski 1977 - Stanisław Franciszek Kolbuszewski. Jana Karigera Słownik polsko-łotewski, Poznań: UAM.

Kurmin 1858 - Słownik polsko łacińsko łotewski, ułożony i napisany przez xiędza Jana Ku rmina, Wilno.

Leskauskaité, Mikulènienè 2010 - Asta Leskauskaitė, Danguolè Mikulènienè. The Presentation of Dialectal Data in the Maps of the Atlas of the Baltic Languages. - In: Acta Baltico-Slavica 34. - Warszawa: Instytut Slawistyki PAN, Towarzystwo Naukowe Warszawskie, p. 57-72.

LKA - Lietuviu kalbos atlasas: vol. 1. Leksika, Vilnius: Mokslas, 1977.

LVDA - Latviešu valodas dialektu atlants. Leksika (autores: B. Bušma ne, B. Lau mane, A. Sta fecka, darba zin. vad. B. La u ma ne). - Riga, 1999.

ME I-IV - K[ārḷa] Mülenbacha Latviešu valodas vārdnīca 1-4. Rediḡējis, papildinājis, turpinājis J[ānis] Endzelīns, Rīga: Izglìtības ministrija, 1923-1932.

Mikulènienè, Stafecka 2011 - Danguolè Mikulènienè, Anna Stafecka. Iš lietuvių ir latvių tarmètyros istorijos: leksikos klausimai Eduardo Volterio programose, Baltistica. XLVI (1). - Vilnius: Vilniaus universitetas, 123-133.

Mikulènienè, Stafecka 2012 - Danguolè Mikulènienè, Anna Stafecka. Geolinguistic Research into the Lexicon of the Latvian and Lithuanian languages. - In: Atlas of the Baltic Languages. Lexis 1: Flora..., p. 359-388.

Sabaliauskas 1958 - Algirdas Sabaliau skas. Dèl baltų kalbos svogūno pavadinimų kilmès, Lietuvos TSR Mokslu akademijos darbai 2 (5), 171-177.

Sabaliauskas 1990 - Algirdas Sabaliauskas. Lietuvių kalbos leksika, Vilnius: Mokslas.

Skardžius 1996-1999 - Pranas Skardžiu s. Rinktiniai raštai I-V. Parengė A. Rosinas, Vilnius: Mokslo ir enciklopedijų leidybos institutas.

Sławski - Słownik prasłowiański. Opracowany przez zespół Zakładu Słowianoznawstwa PAN pod red. F. Sła wski ego, t. 1-8, Wrocław-Warszawa-Kraków-Gdańsk: Zakład Narodowy im. Ossolińskich Wydawnictwo Polskiej Akademii Nauk, 1974-2001.

Smoczyński 2007 - Wojciech Smoczyński. Słownik etymologiczny języka litewskiego, Vilnius: Vilniaus universiteto leidykla. 
Ulmann 1872 - Lettisches Wörterbuch. Erster Theil. Lettisch-deutsches Wörterbuch von Bischof Dr. Carl Christian Ulmann. Riga.

Ulmann 1880 - Lettifches Wörterbuch von Ulmann und Brafche. Zweiter Theil. Lettifchesdeutfches Wörterbuch mit Zugrundelegung des von Bifchof Dr. Carl Christian Ulman n zurükgelaffenen Manufcript bearbeitet von Gustav Brafche. Riga u. Leipzig.

Urbutis 1981 - Vincas Urbutis. Baltu etimologijos etiudai, Vilnius: Mokslas.

Zinkevičius 1997 - Zigmas Zinkevičius. Dél balsių $a, o, e, \dot{e}$ kaitos slavizmuose, Lietuviu kalbotyros klausimai 37, 196-200.

Даль 1989-1991 - Владимир Да ль. Толковый словарь живого великорусского языка, 1-4, Москва: Русский язык.

ЛАБНГ І - Лексічны атлас беларускіх народных гаворак, т. 1. - Мінск, 1993.

ОЛА - Общеславянский лингвистический атлас. Серия лексико-словообразовательная. Выпуск 4. Сельское хозяйство. - Братислава, 2012.

Фасмер I-IV - Макс Фасмер. Этимологический словарь русского языка, 1-4, Москва: Прогресс, 1986-1987.

ЭСБМ - Этыммалагічны слоўнік беларускай мовы, т. 1-13. - Мінск, 1978-2010.

ЭССЯ - Этимологический словарь славянских языков, 1-30. Отв. ред. О. Н. Трубачёв, Москва: Наука, 1974-2003.

\section{АТЛАС БАЛТИЙСКИХ ЯЗЫКОВ: НАЗВАНИЯ РАСТЕНИЙ СЛАВЯНСКОГО ПРОИСХОЖДЕНИЯ}

\section{PEЗЮME}

В статье рассматриваются названия растений славянского происхождения в диалектах единственно живых балтийских языков - латышского и литовского. Исторически эти славянизмы были заимствованы региональными территориальными диалектами, которые в настоящее время исчезают.

В 2009 г. был опубликован пилотный проект Атласа балтийских языков, включающий 12 геолингвистических карт с комментариями на латышском, литовском и английском языках. В 2012 г. первый том атласа: Атлас балтийских языков. Лексика I: Флора - был опубликован в формате CD.

Связанную с растительним миром лексику представляют названия, обозначающие: 1) дикорастущие растения - например, василек, крапиву, подорожник, тысячелистник, одуванчик, 2) культурные растения - например, лук, картофель, репу, (зимнюю) пшеницу, и 3) деревья (можжевельник, орешник, грушу и др.), а также части деревьев (макушку дерева, шишку).

В качестве основных групп заимствованных названий растений можно выделить:

1. Общие заимствования, которые встречаются в широком ареале в Литве и во всей восточной части Латвии - в Латгалии. Обычно это названия овощей и фруктов, 
например, картофеля (Solanum tuberosum) - лат. bulve и вар., bul̨ba и вар., ul biks / лит. bulve и вар., bulbe и вар., чеснока: лат. casnags, casnāgs и вар./ лит. česnākas, šešnākas и вар.

2. Общие заимствования, которые встречаются в широком ареале в Литве и в некоторых говорах Латгалии, например, лит. vosilka / лат. vasilka 'василёк (Centaurea cyanus)', лит. kriváunykas и вар. / лат. kravavniks и вар. 'тысячелистник (Achillea millefolium L.)'.

3. Славянизмы несовпадающего происхождения в латышском и литовском языках, например, лат. klevers (< рус. клевер, бел. диал. кле́вер, клевір) / лит. kaniušina < бел. канюшына, поль. kопісzупа 'клевер (Trifolium)'.

Атлас балтийских языков отражает языковые контакты и служит важным источником для дальнейших исследований не только в балтистике, но также в славистике и индоевропейском сравнительном языкознании.

Słowa kluczowe: języki bałtyckie, dialekty, zapożyczenia słowiańskie, Atlas języków bałtyckich.

Keywords: Baltic languages, dialects, Slavonic borrowings, Atlas of the Baltic Languages.

Ключевые слова: балтийские языки, диалекты, славянские заимствования, Атлас балтийских языков. 